\title{
Economic Aspects of Transportation
}

\author{
V. Máca \\ Charles University Environment Center, Prague, Czech Republic
}

\author{
A. Daňková*, J. Jedlička, R. Haitmarová \\ Transport Research Centre, Brno, Czech Republic \\ *Corresponding author: alena.dankova@cdv.cz
}

DOI: $10.2478 / \mathrm{v} 10158-011-0008-6$

\begin{abstract}
Economic tools lead to the elimination of all unfavourable environmental externalities of economic activity. This provides a solution to the issue of property rights and the full application of the principle " the contaminator pays", with the goal that prices would reflect all costs, including the externalities. The individual economic tools have diffrent forms, such as various payment systems, and recently the even more stressed environmental tax reform. Market-compatible tools are gradually being applied as well. A definite requirement is the cancellation of environmentally harmful subsidies, which still exist in practically all countries in the field of energy and transport.
\end{abstract}

KEY WORDS: transport, economical tools, taxation, road toll, external costs.

\section{INTRODUCTION}

Regarding transport, health and the environment are very important economic aspects, since the transport costs are among the most significant factors affecting behaviour of people in transport, choice of means of transport for travelling, and subsequently the emission as well as noise production. Nevertheless, some costs are not included in the price of transportation, and in that case we refer to the so-called externalities (external costs of transportation) which are described in this chapter in more detail. The transport economy, which not only deals with costs, but also with the benefits of transportation, has been developing since the beginning of the $20^{\text {th }}$ century; some of the concepts used are even older. In the beginning, the major attention of transport economists was paid to the regulation of rail transport and its effective use; approximately from the middle of the $20^{\text {th }}$ century the issue of resource allocation (distribution) was explored comprehensively in transport. The demand and supply research was developed - particulalry the cost and production theory and the customer demand theory, and also the issues of charging and the efficiency of transport investments, effects of regulation on the behaviour of the operators and on the transport development.

Transport is special for the fact that its outcome (product) is the transport of certain goods or passengers from their origin to their destination within a certain time period. The basic units which express the transport production are person-kilometres and tonne-kilometres. the time period of transport is of high importance as well: the highest demand for transport 
(mainly passenger) is usually in the morning and afternoon hours of week days and at the beginning and at the end of holidays. However, other transport quality parameters have a great impact on the demand of both the quality of the traffic routes, the reliability, and comfort of the means of transport.

Another typical feature of transport is the high degree of statutory regulation which includes prices, access, and the operation of the majority of transport modes. The justification of this regulation is based on the fact that the government usually funds a considerable part of the transportation costs, such as the necessary infrastructure; and in addition it guarantees its maintenance, transport serviceability for public, and enforces the traffic regulations. However, the resources allocated for the funding of traffic safety policies and activities are not unlimited. Therefore, their effective use should be decided on. In this way, the investments in new projects should be beneficial.

\section{PRIVATE AND SOCIAL COSTS AND BENEFITS}

Transport, as well as any other human activity, is linked to certain costs and benefits. Some costs are obvious, while we usually do not realize about others. Fuel, used by means of transport, is among the obvious costs. However, the costs caused by the exhaust gas emissions are usually not included in our decision-making process and we would have difficulties to estimate them; this concerns with the external costs of transport. Who bears the costs is of high significance as well. It could be a consumer (a passenger buys a train ticket), the government, and, through taxes, the whole society (the government decides about a new motorway construction), or some other person (an owner of the house by a noisy road who invests in the insulation of windows due to excessive noise). It is necessary for effective market functioning that prices truly reflect all costs. If it does not happen, we refer to market failures.

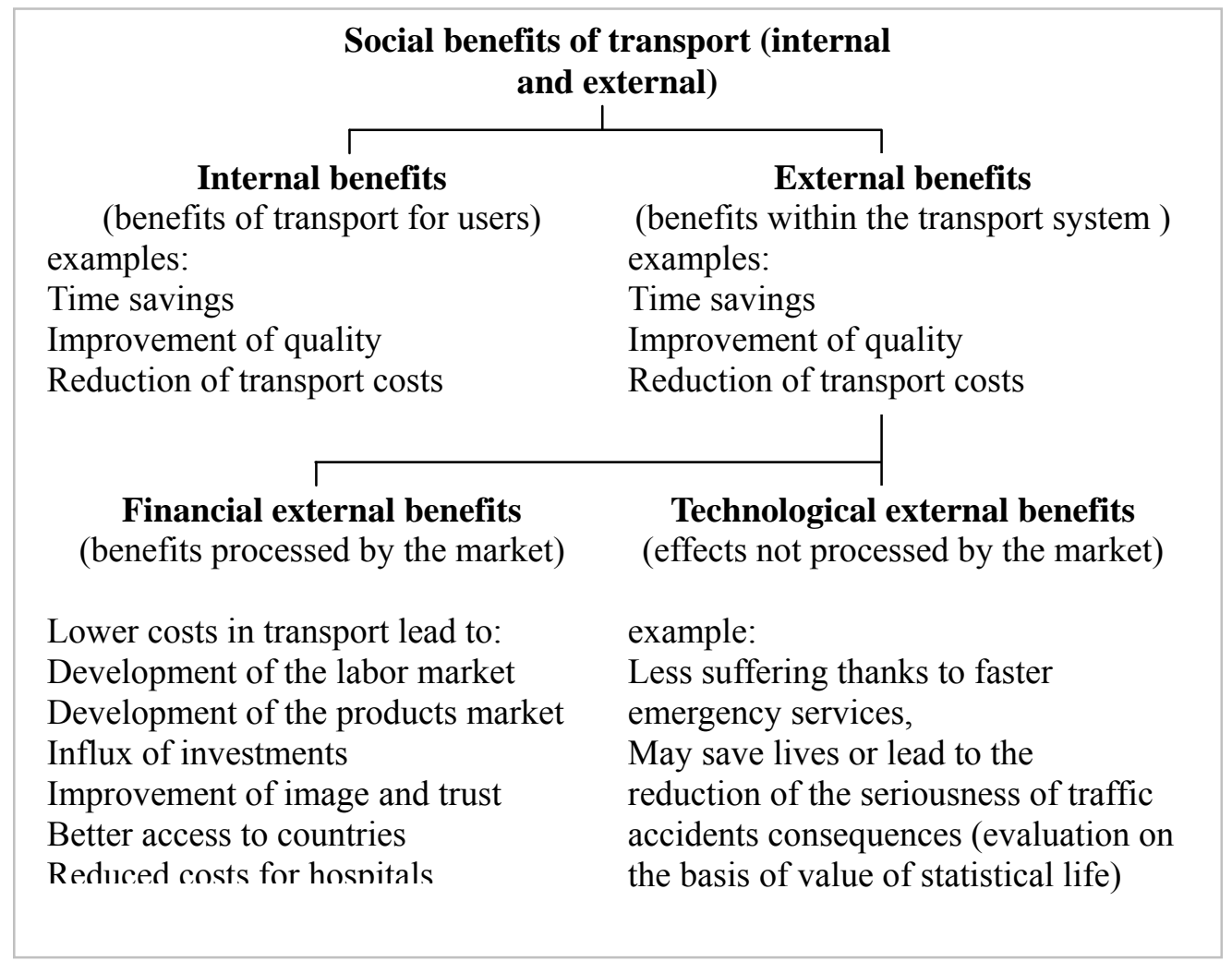

Figure 1: Social benefits of transport (OECD, 2001). 
The transport benefits and costs could be divided into private and social ones. The private benefits are the benefits for those who use transport specifically; these benefits include time savings, and the better availability of goods. The private costs are resources spent by the users of transport - either on the car operation or on its maintenance, or a ticket for city public transport. The social benefits of transport are the benefits for all subjects within the society, i.e. altogether for the transported subjects and for those not using a specific transport service. The definition of the positive external effects of transport is much more problematic. Generally, transport has a whole range of benefits, however, the majority of these benefits are "individualized", i.e. the social benefits are equal to individual benefits, in contrast to the social costs, which are higher than the individual costs in transport. Therefore, it is not the case of typical positive externalities but a consumer surplus (example.g. travel time saving, higher comfort of travelling thanks to the higher quality of the transport infrastructure, etc.).

\section{EXTERNALITIES AND THEIR POSSIBLE INTERNALIZATION}

The concept of externalities is widely known and used in economics, yet there is no complete agreement about its exact definition and interpretation. It is generally accepted that externalities represent an example of market failures, which concern costs transferred by the given subject to other subjects without receiving any compensation, or benefits which the given subject brings to others without receiving any compensation. The existence of externalities is usually related to the absence of property rights, which particulaly applies for various environmental components, such as air, the ozone layer, water, and wild animals. In case the externalities increase benefits for others, we call them positive externalities or external benefits. The negative externalities decrease benefits for involved parties. These external effects have a considerable impact on the environment quality (Verhoef, 1994). In the transport sector, the negative externalities appear very often, the most serious being traffic accidents and the emissions of exhaust gases from road motorised traffic. Traffic accidents cause the loss of human life and damage to human life; material damage occurs as well. Among others, the air pollution by emissions causes damage to human health, damage to material properties (faster corrosion, lower life span of plasters, etc.), damage to forests, and agricultural production damage (see Table 1). These all bring about additional costs. The socially effective solution to the issue of externalities is not the total prevention of their existence, as it may seem in relation to the production of emissions of harmful gases, but the incorporation of external costs into market prices, which would reflect the social costs in the future (Holman, 2002). We speak about the internalization of externalities in this case. However, the primary prerequisite for the internalization of externalities is their evaluation. It is the evaluation of goods and services of the environment that are among the most discussed issues of environmental economics; and the evaluation methods of the total service and goods value of the environment are not yet fully developed and accepted (Rothengatter, 2003).

There is a range of approaches for internalizing the externalities which all count on public interference at some degree. Probably the most often mentioned approach in the neoclassical economics is the Pigovian tax approach. This tax is imposed on an externality producer amounting to the difference between social and private costs, which leads to reducing the production of the externality to a socially optimum, level. Hypothetically, Pigovian taxes are ideal taxes, but, because of the difficulties in their determination (i.e. determination of the amount of an externality and its producer), monitoring, and checking, their implementation in the real world is difficult. 
The community of liberal economists, mentions Coase's theorem (Coase, 1960) very often. According to the American economist R. Coase, under the condition of negotiating with zero costs, it is possible to reach an effective solution to the dispute via negotiations between the pollution producer and its receiver. The necessary assumption of this negotiation is the fact that one of them has property rights to certain property and reaching the agreement is not based on any transactional costs. The whole situation can be shown in an example. My neighbour's fruit tree interferes with our garden, where it casts a shadow (this is a negative externality for us). Doing so limits our ownership property rights, and therefore we can visit our neighbour and come to an agreement. For example, the neighbour could share the harvest with us, offer us a financial compensation, or, in the most extreme case, chop the tree down, and in one of these ways internalize the caused the externality. However, in the case of externalities caused by transport, the negotiations are, considering the huge number of producers and the damage, virtually impossible, and there are no zero transactional costs.

Table 1: Overview of externalities in transport.

\begin{tabular}{|l|l|}
\hline \multicolumn{1}{|c|}{ Field } & \multicolumn{1}{c|}{ Externalities } \\
\hline Traffic accidents & $\begin{array}{l}\text { Injury*, death*, permanent effects*, psychological damage to relatives*, } \\
\text { material property damage*, costs for emergency services*, fire brigade*, } \\
\text { police*, environmental damage caused by accidents*, loss of production*, } \\
\text { payments to widow, orphan pensions and other costs. - see Figure 2 }\end{array}$ \\
\hline Air pollution & $\begin{array}{l}\text { Effects on health - respiratory and cardiovascular diseases, damage } \\
\text { to agricultural production, forest ecosystems, more intensive corrosion }\end{array}$ \\
\hline $\begin{array}{l}\text { Greenhouses gases } \\
\text { (climate change) }\end{array}$ & $\begin{array}{l}\text { Effects on health, agricultural production, ecosystems; water stress, } \\
\text { desertification, rising sea and ocean levels, etc. }\end{array}$ \\
\hline Higher noise level & $\begin{array}{l}\text { Discomfort of the population, health damage - hearing disorders, increased } \\
\text { risk of heart attacks and cardiovascular diseases, sleeping disorders, effects } \\
\text { on the performance of people }\end{array}$ \\
\hline Congestion & Time losses*, increased emissions of vehicles in queues \\
\hline $\begin{array}{l}\text { Building of transport } \\
\text { infrastructure }\end{array}$ & $\begin{array}{l}\text { Fragmentation of landscape (impact on biodiversity), decrease in the number } \\
\text { of animals, land-use, pollution of surface water, threat to ground water }\end{array}$ \\
\hline
\end{tabular}

Note: ${ }^{*}$ the mentioned effects are not always and complete externalities

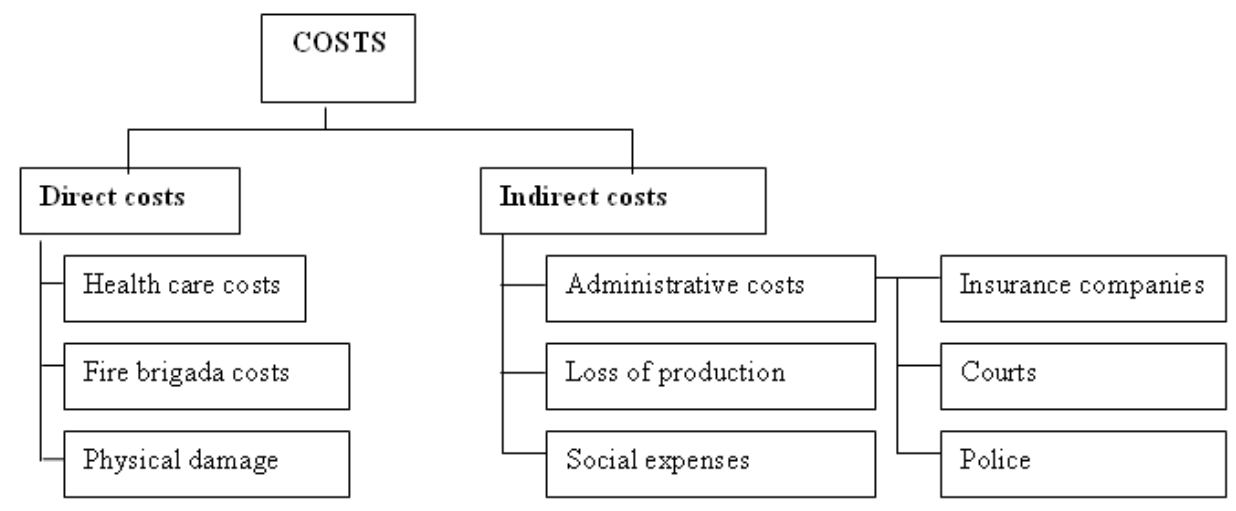

Figure 2: Overview of costs and losses caused by traffic accidents. 
Although there is general agreement about the fact that in terms of social efficiency it is necessary to internalize external costs, the open issue is whether to internalize the marginal or average external costs. Marginal costs are costs which are caused by additional means of transport (vehicle, train, boat, airplane) when using the transport infrastructure. The scientific discussion in European strategy documents is reflected in the effort to charge transport in the form of short run marginal social costs. These are costs that are covered by the society and are applied to every additional driven kilometre or another journey. They include infrastructure costs and costs which were caused by a vehicle to other road users and the rest of the society (mainly the costs of damage caused by emissions, noise, accidents, etc.). This charging ensures that the capacity of the transport network is maintained at a socially optimum level. But there are some technical problems related to marginal costs, and they concern the method for their determination and selection for each individual vehicle due to excessive variability and growth coming with another vehicle.

\section{ECONOMIC TOOLS}

There is currently no unified classification of transport regulation tools and it is often possible to find a different division among various authors dealing with this topic. Basically, the generally accepted basic classification divides the used tools into market-conforming tools (economic) - which are tools of fiscal policy (taxes and fees), tradeable permits, and others (e.g. bails or insurance) - and normative tools, which are based on prohibition and orders, limits, standards, and prescribed administrative procedures (Kubátová \& Vítek, 1997). The economic tools change the relative prices of products and services (i.e. changes in prices to one another), or they change the household and company incomes which leads to the change of consumers' and producers' behaviour. Compared to normative tools, the economic tools offer a range of advantages - they usually allow for higher flexibility to achieve the goal, motivate for a faster introduction of new technologies, tend to be less administratively expensive, and may bring additional income to public budgets.

\subsection{Fees and taxes}

Fees and taxes are basic economic tools of all countries; they are a decisive component of income of state budgets. In contrast to taxes, which are defined as mandatory, payments of irretrievable and non-equivalent nature specified by law, fees are related to a certain reciprocal service or another counter-value. However, in practice these terms are often confused, which may cause a situation where the fee for the release of polluting sunstances in the air is an environmental tax. Taxes and fees concerning road transport are mentioned in Table 2.

Table 2: Overview of taxes and fees in transportr (Kubátová \& Vítek, 1997).

\begin{tabular}{|l|l|}
\hline \multicolumn{1}{|c|}{ Fees } & \multicolumn{1}{c|}{ Taxes } \\
\hline Motorway stickers & Vehicle registration tax \\
\hline Toll fee & Circulating taxes from vehicles \\
\hline Exceptional load fees & Fuel excise tax \\
\hline Parking fees & \\
\hline City centre traffic, or other locality, fees & \\
\hline
\end{tabular}


With the exception of vehicle registration tax and the exceptional load fee, all the abovementioned types of taxes and fees are used in the Czech Republic. In the case of other (nonroad) transport modes, a smaller range of economic tools is usually used, with the most common being fuel excise duties, infrastructure access fees (e.g. the use of railways), but there could be other reasons as well (example.g. charging the noise in air transport).

\subsection{Excise duty and road tax}

Excise duty and road tax are among taxes linked to the environment because their tax basis has a special relationship with the environment, in spite of the fact that they are primarily collected for different purposes than the protection of the environment. It is related to indirect taxes, which are taxes imposed on goods and services. The subjects of the excise duty on mineral oils are not only mineral oils, but also all products used for engine drives and an defined list of products, as well as their mixtures, used for the production of heat.

Mineral oils used as fuel for air transport (with the exception of recreational flying), some waste oils, pure bio-fuels, and some other products are exempt from taxation. The current tax rate for unleaded petrol is CZK 11.84 per litre, CZK 9.95 per litre for diesel (medium oils and heavy gas oils), and CZK 0.472 per kilogram for heavy heating oils. The total income of the excise duty regarding mineral oils is less than CZK 70 billion a year. A part of this yield is allocated into the State Transport Infrastructure Fund (SFDI). Previously, it used to be $20 \%$, since 2005 this share has decreased to $9.1 \%$ (in absolute terms of the income got reduced by CZK 7.4 billion). The reason for this reduction was an administration transfer of the second and third class roads to regions which were also given corresponding financial resources. Within the EU some rules concerning the taxation of energies are harmonized; and the minimum level of taxation for the main types of energy products, depending on their usage, and conditions for rate exemption or a reduction for the selected energy products (e.g. bio-fuels) or specific uses, (e.g. aviation) are determined. In the following table a comparison of the excise duty rates for unleaded petrol in individual member states is shown.

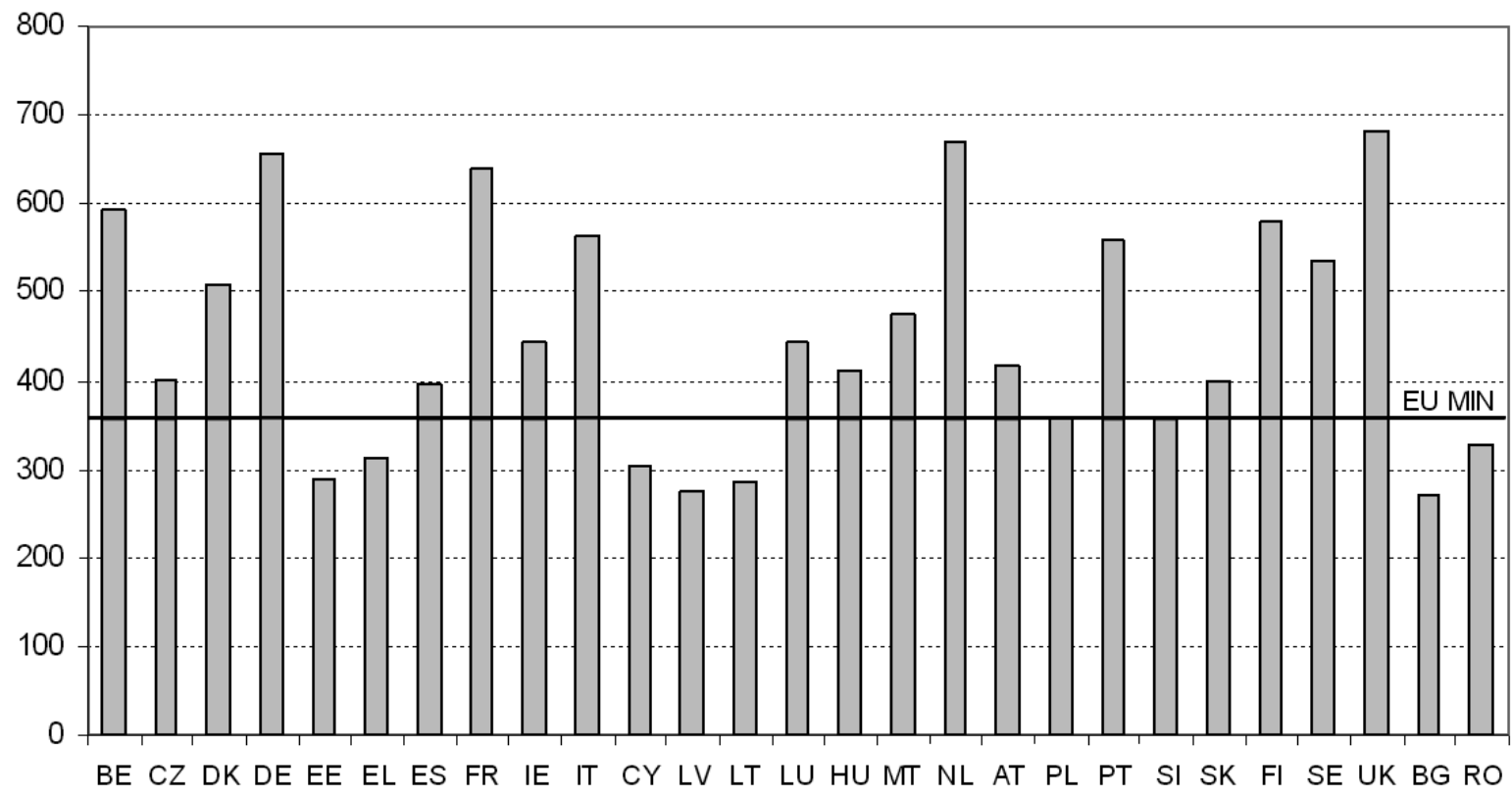

Figure 3: Taxation of unleaded petrol (excluding VAT) in the countries of EU-27in $€ .1000 \mathrm{I}^{-1}$ (European Comission, 2007). 
Another tax which is related to the environment is the road tax, which is imposed on trucks and passenger cars used for business purposes. The yearly rate of road tax for passenger cars ranges from CZK 1200 - 4200 according to the engine displacement. The road tax for trucks depends on the vehicle weight and the number of axles, and may even amount to CZK 50400 a year (3 axles, weight over 36 tons). Vehicles providing domestic passenger transport and vehicles with electric drives are among those which are tax exempted. The total yield of the road tax was CZK 5.51 billion in 2004.

Regardng the road tax, there is a partial harmonization within the EU, which only concerns trucks, for which the minimal tax rates are determined depending on the number of axles and total weight. A proposal for the harmonization for the taxation of passenger cars, which should reflect the volume of emissions of the main greenhouse gas carbon dioxide, is currently being discussed in the EU.

\subsection{Charging the transport infrastructure}

As it has been repeatedly mentioned, transport infrastructure charging tools should reflect the extent and period of its use. In road transport there are two approaches to charging which are currently widespread - time, and since January 2007 performance as well,. Whereas the time charging only reflects the period of use of certain infrastructure, performance charging enables the calculation of not only the period of use, but also the number of driven kilometres. In the Czech Republic, both systems are used for charging toll on selected roads - time charging ("motorway sticker") for motor vehicles with their weight under 12 tons and a performance charging - toll for vehicles over 12 tons.

Rates of the time fees are determined according to weight, whereas in case of the toll, the rates are determined according to emission classes and number of axles. Three versions of validity are set for the time charging (yearly, monthly, 7 days). The yearly rate in 2007 was set to CZK 900 for vehicles up to 3.5 tons and CZK 7000 for vehicles from 3.5 to 12 tons. The toll rates are set according to the number of axles and emission classes of vehicles, from CZK 1.7/km, for vehicles EURO 3 and higher with 2 axles, up to CZK $5.4 / \mathrm{km}$, for vehicles EURO 2 and lower with 4 and more axles (the individual rates are shown in table $3)$. Revenues from the sale of motorway stickers and from the toll collection are the income for the State Transport Infrastructure Fund, which funds the development, construction, and modernization of roads and highways, railways, and inland waterways.

Table 3: Toll rates in 2007.

\begin{tabular}{|c|c|c|c|c|c|}
\hline Emi & & and older & emissi & $S$ EUI & ind newer \\
\hline \multicolumn{6}{|c|}{ Number of axles } \\
\hline 2 & 3 & 4 and mor & 2 & 3 & 4 and more \\
\hline \multicolumn{6}{|c|}{ Rate of toll $(\mathrm{CZK} / \mathrm{km})$} \\
\hline 2.3 & 3.7 & 5.40 & 1.70 & 2.90 & 4.20 \\
\hline
\end{tabular}

Source: Ministry of Transport

The toll is either paid in advance through a subscription ticket before entering the charged road, or after the use of the road in regular billing cycles, which are based on the agreement between the electronic toll operator and the vehicle operator. Both fixed and mobile control devices continuously check the toll payments. The vehicles for which the toll was not required, or was required in the wrong way, are automatically identified and handed over to mobile control. The customs administration officers of the Czech Republic, who are legally authorized to stop vehicles, check the discrepancies in toll charging, and impose a fine or start an administrative action, or even impound the vehicle. All motorways and dual 
carriageways, with the exception of some sections, in the Czech Republic are charged. There is currently a plan to extend the charged infrastructure with I. class roads or with the whole road network, and charging the vehicle category of 3.5-12 tons and passenger cars is being taken into consideration as well.

In rail transport, the obligation is to pay for the assignation of the capacity of the railway, for its use, for providing the operation of the railways, and for other provided services.

\subsection{Subsidies}

A subsidy is considered to be a measure which maintains the consumer prices under the market level or the production prices above the market level. A special category of subsidies are the environmentally harmful subsidies; they provide financial or different benefits for certain products, procedures, or areas in contrast to environmentally more friendly alternatives.

One of the most common forms of subsidies is state support. These are selectively provided resources from the government or public administration which provide the recipient with a benefit which would otherwise be out of reach for them. It results in an interference in the market environment; the conditions for competition have changed. In transport sector, the typical examples of the state support are the tax-reliefs or support of public transport. For example, in 2005, Czech Railways were covered a contribution for the economic loss from the passenger rail transport operation in the amount of CZK 2.12 billion. Similarly, regions cover demonstrable loss to operators who operate public bus transport to ensure the transport service within a certain area.

The government also provide subsidies for the purchase of vehicles for public transport and city public transport; special emphasis is put on supporting vehicles using environmentally friendly drives. The support is available for operators who provide transport services within an area or operate city public transport. The amount of subsidies for the renewal of bus fleet is provided in fix amounts which can reach up to $30 \%$ of the acquisition cost of buses.

Regarding the amount of provided resources, the state budget grants for the construction of the transport infrastructure are the most important. They are usually provided by the State Transport Infrastructure Fund (SFDI). The construction of motorways and railway corridors are among the most important investment projects of recent years. The costs for the construction of the first and second transit railway corridor were to be equal according to the original plan, CZK 36500 million for each corridor. The State support was to amount CZK 14810 million for first corridor, andCZK 18870 million for the second corridor. Providing the state guarantee for the majority of loans related to the construction of the above mentioned corridors may also be considered as a form of the state support.

One of the types of sustainable transport support measures may be the price assignment of the services of public passenger transport into the reduced rate of VAT. In the Czech Republic, prices of public passenger transport and luggage, including passenger road and rail transport, other passenger transport and underground transport apply for the reduced VAT rate. The reduced VAT rate is further applied for the prices of water and air passenger transport and luggage. Whereas in case of the rail transport it is the support of an environmentally friendly mode of transport, in case of air transport, which causes a higher environmental impact, their inclusion in the reduced VAT rate is environmentally harmful. The situation is similar with international air transport, where VAT is not applied at all in some cases, on the basis of international agreements.

Another example of environmentally harmful subsidies is the different taxation of petrol and diesel. This difference is an example of a relic from the past and has purely economic 
reasons. Diesel was mainly used by trucks and its lower taxation should have increased the competitiveness of transport operation in international transport competition.

\subsection{Tradable permits}

Tradable permits are most commonly used for the reduction of emissions to a preset level which corresponds with the quantity of issued permits. This is different from environmental taxes where the tax rate is known in advance, but the volume of the emission reduction is unknown; in the case of tradable permits the situation works the other way round the volume of the emission reduction is known but the price is unknown.

The trading system with the permits for $\mathrm{CO}_{2}$ emissions has been in operation in the EU since 2005 and only concerns the stationary sources of pollution. However, at the end of 2006 the European Commission presented a proposal according to which domestic and intracommunity flights which land or take off from airports within the EU would be included in the emission permits trading scheme in 2011.

\subsection{Insurance}

Insurance is an economic tool which has a specific significance in the transport sector because through the compulsory insurance contract the issue of responsibility for damage caused by the vehicle operation in road transport is dealt with. The corresponding Act also determines, among other things, the minimum insurance limits for the compensation of damage to health or death, material damage, lost profit and costs for claiming compensation Similarly, there is a mandatory liability insurance for rail transport, as well as for air transport with certain specifications.

\section{SUMMARY}

Economic tools seek to eliminate all unfavourable environmental externalities of economic activities (Moldan et al., 1997). This mainly concerns the solution of the property rights issue and the full application of the principle "the polluter pays", so that the prices reflect all costs, including the externalities. The individual economic tools have various forms, such as various payment systems, and the recently more and more emphasized environmental tax reform. Market-compatible tools, such as tradable permits, are gradually applied as well.

The definite requirement is the cancellation of all environmentally harmful subsidies which still exist in virtually all countries in the fields of energy and transport.

\section{ACKNOWLEDGEMENTS}

The research described in this article was performed within the scope of a research project of the Ministry of Transport of the Czech Republic No. MD 04499457501 "Sustainable Transport - Chance for the Future". 


\section{REFERENCES}

Coase, R.H., 1960. The problem of social costs. Journal of Law and Economics, vol. III, pp. 1-44.

Daňková, A., Koňárek, Z., 2007. Metodika výpočtu ztrát z dopravní nehodovosti na pozemnich komunikacích. Brno: Centrum dopravního výzkumu. (in Czech)

European Comission, 2007. Excise Duty Tables: Part II - Energy products and Electricity. Brusel: European Commision, 43 p.

Holman, R., 2002. Ekonomie. 3. akt. vyd. Praha: C.H.Beck, 714 p. ISBN 80-7179-681-6. (in Czech)

Kubátová, K., Vítek, L., 1997. Daňová politika: Teorie a praxe. Praha: CODEX Bohemia, 264 s. ISBN 80-85963-23-X. (in Czech)

Moldan, B. et al., 1997. Ekonomické aspekty ochrany životního prostředí. 1. vyd. Praha: Univerzita Karlova, 307 s. ISBN 80-7184-434-9. (in Czech)

OECD, 2001. Assessing the Benefits of Transport. Paris: OECD Publishing, European Conference of Ministers of Transport, 216 p. ISBN 92-82-11362-0.

Rothengatter, W., 2003. Environmental Concepts - Physical and Economic. In Henscher D.A., Button, K.J. (eds.) Handbook of Transport and the Environment 4. London: Elsevier, 854 p. ISBN 978-0-08-044103-0.

Verhoef, E., 1994. External effects and social costs of road transport. Transportation Research, vol. 28A, no. 4, pp. 273-287. ISSN 0041-1647. 